\title{
THE HIMALAYAS - A FASCINATING GEOLOGICAL CHALLENGE
}

by

\section{Augusto Gansser}

The spectacular Himalayas play a dominant role in the study of orogens resulting from continental collisions. In this brief pictorial essay, the author touches on some of the regional aspects of the Himalayas' geological and structural evolution, and the potential scientific insight to be derived from further, more detailed studies.

The Himalayas, highest and probably youngest of the world's mountain ranges, separate (for about $2500 \mathrm{~km}$ ) the rapidly sinking Brahmaputra - Ganges and Indus plains in the south from the rising high land mass, the Tibetan highland, in the north.

We know now that the Himalayas resulted from a complex and enigmatic interplay of the Indian plate against Eurasia, the latter representing a puzzle of plate fragments, some still with "Gondwanic" affinities. Foreland (India) and backland (Tibet) contain remarkable geological contrasts, and the Himalayas have inherited elements from both.

The Peri-Indian Suture Zone stretches for over $5000 \mathrm{~km}$, from Karachi in the west to the Andaman islands in the east; the Indian plate has been welded to the complex Eurasian mass along it. This Suture repesents one of the most outstanding structural elements on earth, beautifully exposed but not readily accessible. It has stimulated many theories on its origin - theories which often contradict known field facts: plate tectonic models have had India drifting for thousands of $\mathrm{km}$, while all the field relations suggest that India and Eurasia could never have been far apart.

Much of the fact-finding in the Himalayas, in spite of modern methods, is based on "classical" strenuous fieldwork, though transportation in the foothills has become easier, and some of the planning can now be done with Landsat or other air photography when available. Working conditions in the interior and higher parts of the Himalayas have not changed: without the help of porters or sturdy ponies and yaks, a geological party has difficulty making progress (Fig. 1). Climatic conditions and vegetation can also have adverse effects on field work: progress in the nearly impenetrable jungles of the eastern Himalayas is only a fraction of what can be achieved in the desert mountains of the western Himalayas.

Since its founding in 1851 , the Geological Survey of India has devoted much of its efforts to studying the Himalayas; detailed mapping continues to be the main objective, and a wealth of local information has been gathered. The Geological Survey of Pakistan has more recently, investigated the ophiolitic belts of the Suture Zone and surrounding areas, well known for their chromite occurrences.

Regional research is now being carried out by the Wadia Institute of Himalayan Geology, stationed in Dehra Dun. Named after the greatest Indian geologist, the Institute is sending reconnaissance parties into remote areas of the Himalayas. Geological departments of some universities, such as Chandigahr in India and Peshawar in Pakistan, are carrying out investigations, and the contributions of foreign institutions are substantial. Various Chinese expeditions to Tibet have contributed to clarifying some of the stratigraphic problems. More cooperation and correlation of effort is needed, and this has been the prime aim of the Inter-Union Commission on Geodynamics Working Group 6: "Geodynamics of the Alpine-Himalayan Region, East."

\section{Regional Aspects}

A regional picture of this fascinating mountain range is gradually emerging, although one must remember that only about one third of the Himalayas is really known, and interpretations therefore are generally subjective and may vary considerably (Fig. 2).

Paleogeographically, the Himalayas have evolved on the northern edge of the Indian shield, with its sporadic Gondwana sediments on the Precambrian basement (Lesser Himalayas). Northwards, they gradually become more marine and complete along the Tethyan platform, leading to the famous Tethyan sediments with a conformable fossiliferous pile from the Cambrian to the Eocene (Tethys Himalayas).

The present difference in facies from south to north is emphasized by intracrustal thrusting, bringing more distant deposits, over $100 \mathrm{~km}$ apart, into juxtaposition. This is well expressed on both sides of the Main Central Thrust (MCT) with its pile of $15-20 \mathrm{~km}$ of remobilized basement, which forms the base of the Tethyan sediments - the "Dalle du Tibet" (Fig. 3). This crystalline thrust sheet, coinciding with the High Himalayas, led to the erroneous concept of a once

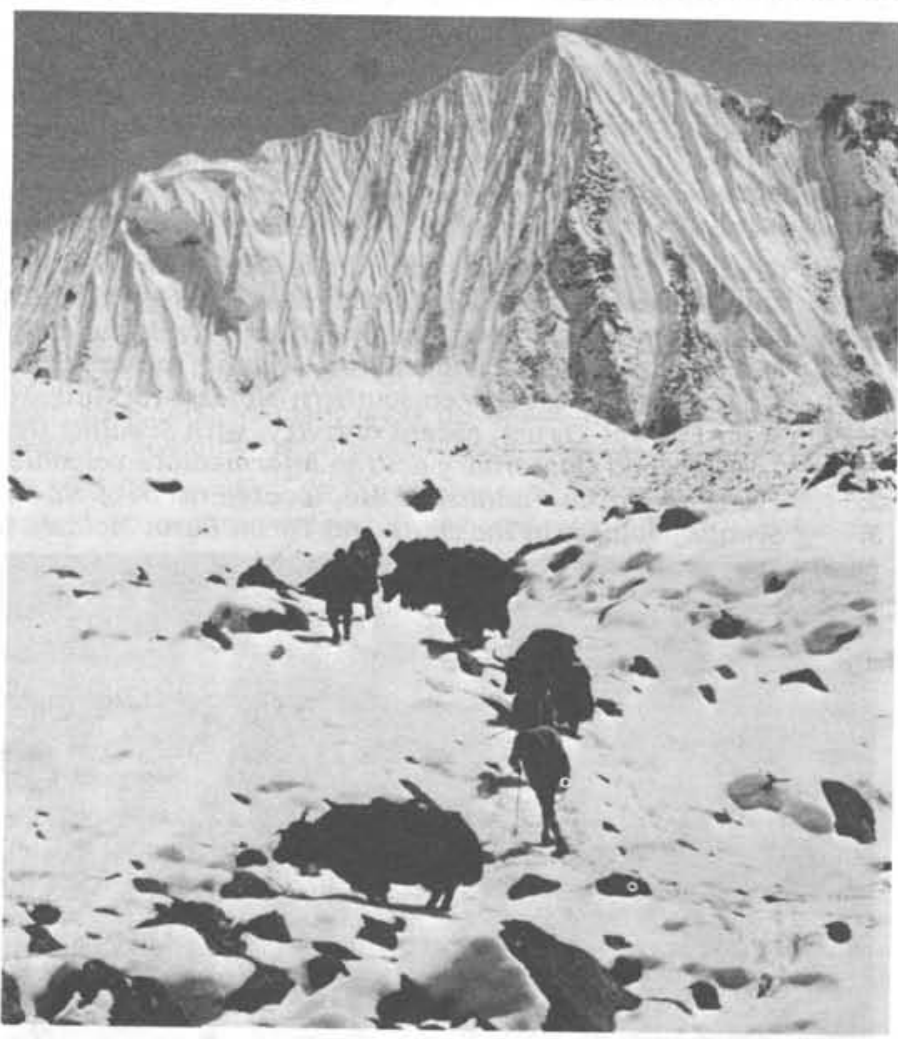

Figure 1. Geological expedition travelling with yaks, crossing $5200 \mathrm{~m}$ Karakachu-La Pass in the High Himalayas, northern Bhutan. 


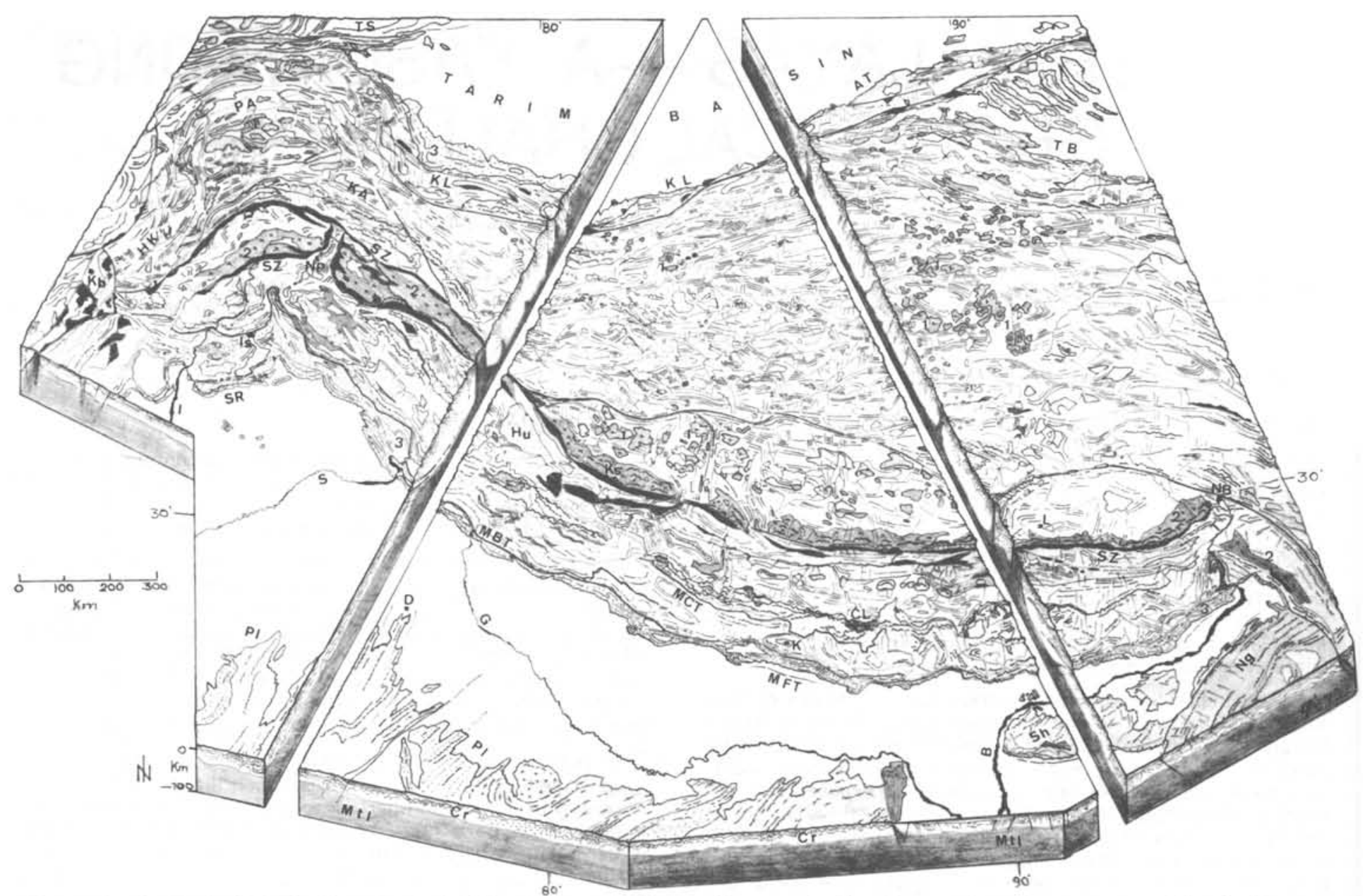

Figure 2. Geological block-diagram of the Himalayas and Tibet. (Photo-reduction from coloured map prepared by A. Gansser, 1979 , from Landsat photos and other available geological information; vertical and horizontal scales are the same).
AI Astin-Tagh, bordering
Hu Hundes Basin
Ks Mt. Kailas
Tarim Basin
I Indus River
L Lhasa
NB Namche Bharwa
Is Islamabad
CL Chomo Lungma (Everest)
D Delhi
K Kathmandu
KA Karakorum
G Ganges River
$\mathrm{Kb}$ Kabul
KL Kun-Lun

$\begin{array}{ll} & \text { Mountain } \\ \mathrm{Ng} & \text { Naga Ranges } \\ \mathrm{NP} & \text { Nanga Parbat }\end{array}$

PI Peninsular India with

Aravalli trend

$S \quad$ Sutlej River

Sh Shillong Plateau

$T$ Tsangpo River

TB Tsaidam Basin

TS Tien-Shan, southern part

$\mathrm{Cr} \quad$ Crust $30 \mathrm{~km}$ under Peninsular India, 70-75 km under Himalayas and Tibet, $30 \mathrm{~km}$ under Tarim Basin

MTL Mantle "obducted" along SZ and older Sutures in central and northern Tibet (Kun Lun)

$S Z$ Himalayan Suture Zone (doubled in western Himalayas)

MCT Main Central Thrust, major intra-crustal fracture (Miocene)

MBT Main Boundary Thrust, on southern Molasse (Siwaliks) (Pleistocene)

MFT Main Frontal Thrust, recent activity, with Siwaliks thrust on Quaternary terraces and fans

1. Tertiary and Quaternary acid to intermediate volcanics in Tibet.

2. Transhimalayan Plutons, $60 \mathrm{Ma}$, located north of SZ with narrow belt of Kailas Molasse in western Himalayas.

3. Siwalik Molasse in the south and Tarim Basin Molasse in the northwest. (Ophiolites (Suture Zones) in darkest grey).

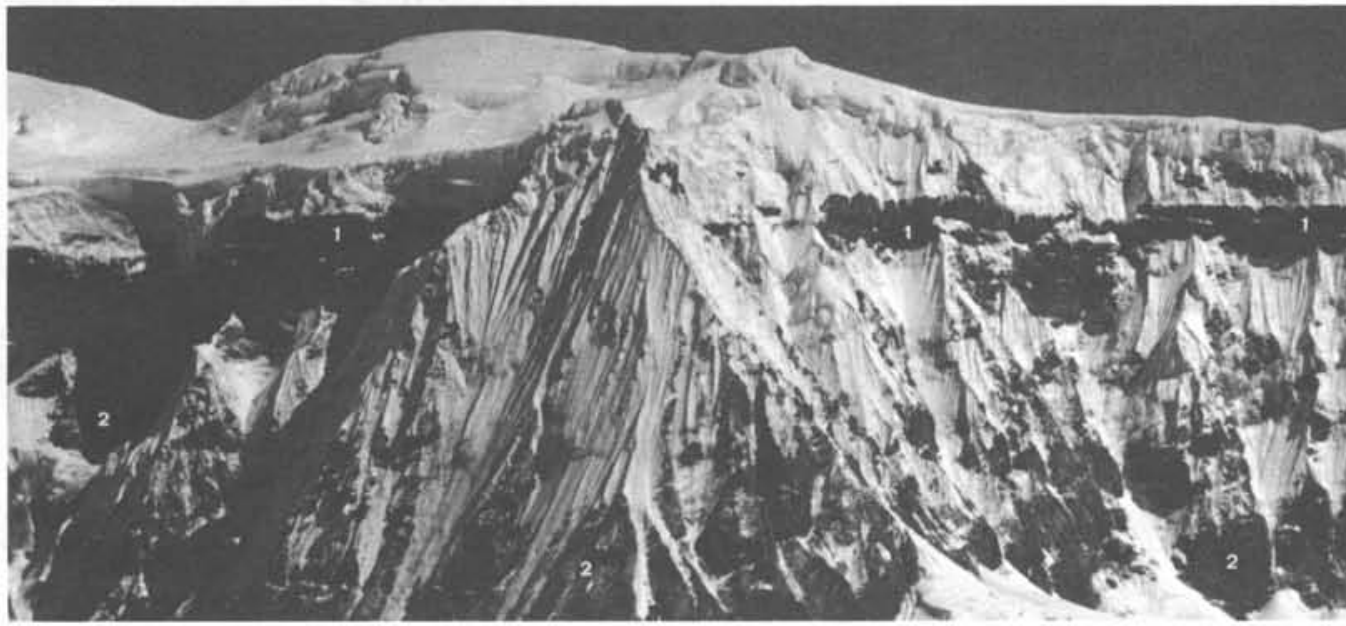

EPISODES, Vol. 1979, No. 4
18
Figure 3. The "Dalle du Tibet": base of Tethyan Himalayas on crystalline rocks of the MCT. (1) slightly metamorphosed Lower Paleozoic Tethys sediments on (2) migmatitic gneisses with dykes of Tertiary tourmaline granites. South flank of Tibetan border range in north Bhutan, summit $7000 \mathrm{~m}$ high. 
dividing crystalline barrier. The Tethyan sediments are folded disharmonically above their crystalline base, often with spectacular backfolding, well displayed in northern Nepal (Fig.'s 4 and 5).

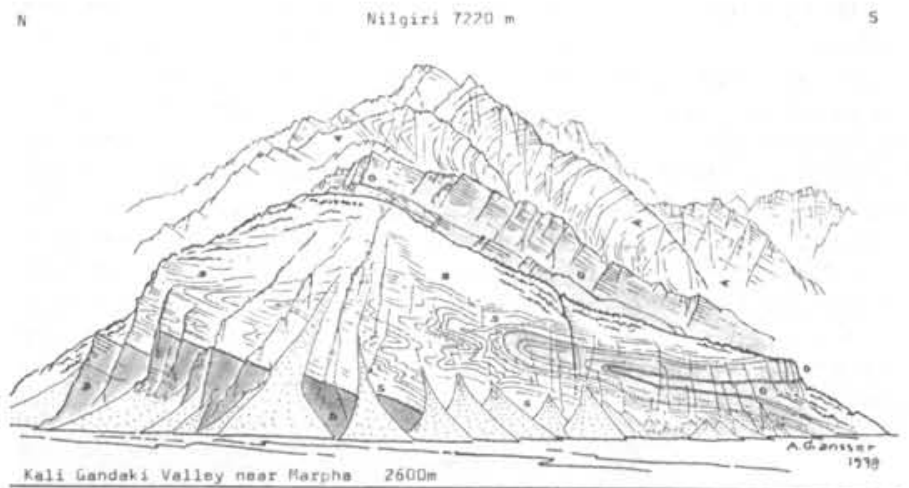

Figure 4. The backfolding of Tethyan sediments above the $M C T$. Reversed section with Devonian (D), Silurian (S), Ordovician (O) and Cambrian (€): Kali Gandaki Valley, northern Nepal. Stratigraphy after Bordet 1971, structural sketch by A. Gansser.

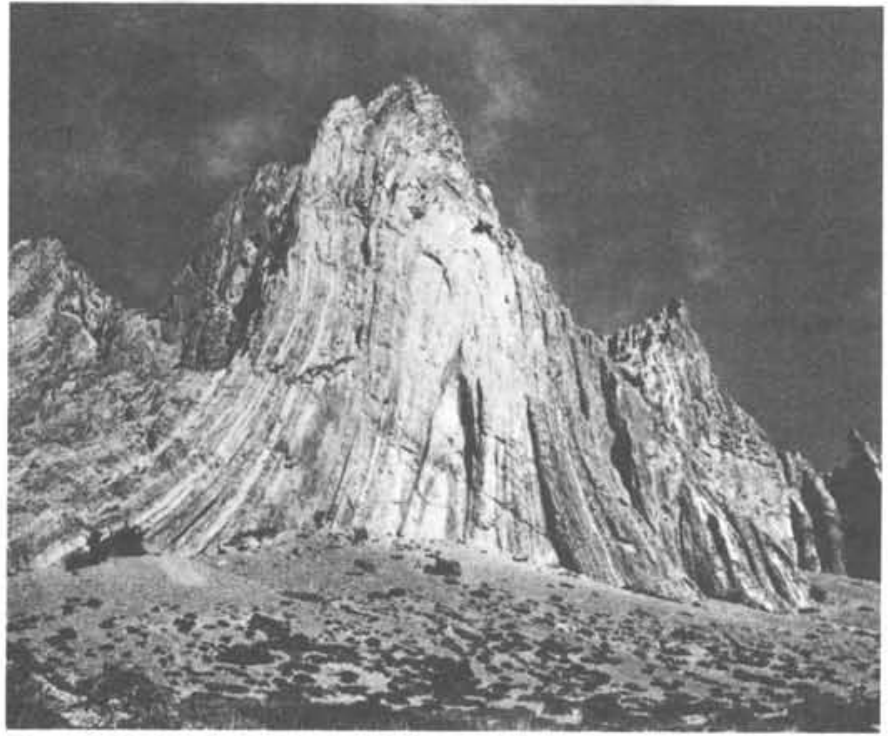

Figure 5. Vertical fold of Triassic limestone, Zanskar range, Northwestern Tethys Himalayas: strongly compressed platform sediments thrust northwards on Suture Zone.

These sediments grade northwards all along the Himalayas into a flysch facies at sites of former steep and unstable continental slopes of narrow, but very pronounced, oceanic basins. This is the northern edge of the Indian plate. Beyond, instead of evidence for extensive and simple oceanic sedimentation, the structure, lithology and petrology of the oceanic rocks indicate steep-walled, narrow basins with island arcs and slices of continental rocks.

It is significant that the corresponding ophiolites are characterized by a near-continuous belt of ophiolitic mélanges within the Suture Zone which extends for $2500 \mathrm{~km}$ along the northern Himalayas. They are highly disrupted and compressed into steep imbrications except for some ophiolitic nappes thrust southwards. The latter show an original structural relationship with a flysch base on platform sediments covered by basic volcanics, well developed ophiolitic mélanges, topped by ultramafic bodies with all the characteristics of mantle slabs. They form the highest structural features in the Himalayas (Fig. 6). This sequence, contrary to the normal succession assumed for oceanic crust and mantle, is recognized not only along the Himalayan Suture Zone, but is also well exposed in the Suture along the Quetta belt to the west.

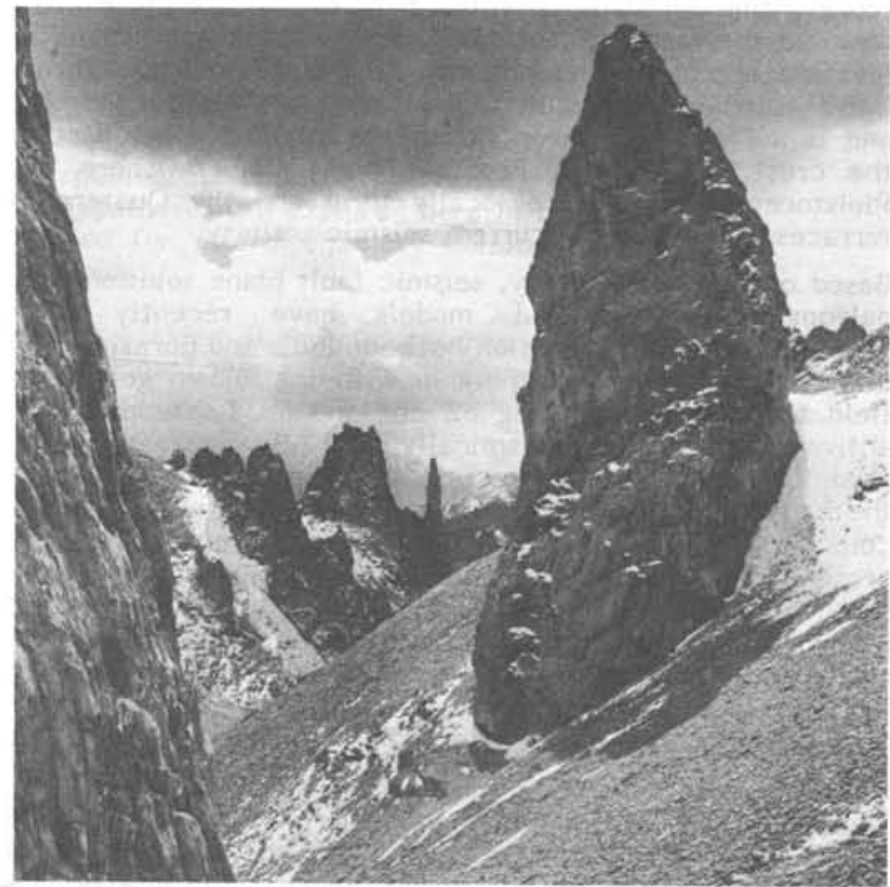

Figure 6. Schuppen-zone along northern border of ophiolite nappe against Zanskar range of Triassic Tethyan platform sediments comprising limestone wedges in flysch and volcanics: view to the East.

Except for the westernmost Himalayas, over $2000 \mathrm{~km}$ of the ophiolitic Himalayan Suture Zone is bordered on its northern side by a narrow but significant belt of Paleogene molasse, which at its type locality, the holy Mt. Kailas in southern Tibet, is over $4000 \mathrm{~m}$ thick (see cover photo). Steeply overthrust (northwards) by the ophiolitic rocks, the molasse transgresses normally on the important Transhimalayan Plutons, which again form a near continuous belt of $2500 \mathrm{~km}$ in length north of the Suture, from the Swat area in northern Pakistan to the legendary Namche Bharwa Mountain at the eastern end of the Himalayas.

The recognition of these plutons as an important unit related to the Suture Zone is new. They are mostly tonalitic, with older basic and younger acid differentiations which intrude Mesozoic and older sediments. Their average age is about 60 $\mathrm{Ma}$, and the low $\mathrm{Sr}^{87} / \mathrm{Sr}^{86}$ ratio as well the structural control suggest an oceanic origin. They are surprisingly similar to the plutons apparently generated by a former subduction zone to the west of the Andes. The Transhimalayan Plutons form the actual border between the Himalayas and the Tibetan highland.

\section{Structural History}

The structural history of the Himalayas and its related metamorphism are unique. Orogenic events accompanied by metamorphism occurred at 1800 and $1400 \mathrm{Ma}$ in the crystalline basement (now located above the MCT) and were followed by a long anorogenic period, interrupted only by epirogenic accidents. The onset of the "youngest" Himalayan orogeny is recorded in Triassic flysch zones in the western and eastern Himalayas. Tectonism increased in intensity in the Upper Cretaceous, and culminated in the Miocene, prior to the main Siwalik molasse sedimentation. A renewed strong metamorphism outlasted the orogeny, but curiously enough, was mostly concentrated in the already metamorphosed basement rocks, and affected the lower part of the 
Tethyan sediments only locally. At this time (late Tertiary) widespread crosscutting tourmaline-bearing leucogranites were developed within the Precambrian crystalline basement.

The phases of the Himalayan orogeny are reflected by major structural accidents. In the North, the Suture Zone (SZ), representing Mesozoic events, involves the complete crust down to the mantle. The MCT, located to the south, is of Miocene age and is intracrustal. The Main Boundary Thrust (MBT), farther south still, follows along the Siwalik foothills and is a Pleistocene event affecting only the upper part of the crust. The Main Frontal Thrust (MFT), where the Pleistocene Siwaliks are locally thrust on the Quaternary terraces, is the locus of current seismic activity.

Based on Landsat imagery, seismic fault plane solutions and paleomagnetism, several models have recently been suggested for the interaction between India and Eurasia. It is difficult to fit most of them in with the known geological field facts. The imposing SZ and the MCT, studded with active hot springs, are seismically dead. By contrast, microseismics, observed in connection with the Darbela Dam near the western Himalayan syntaxis, show trends which do not coincide at all with the known surface features. Though the present SZ marks the border between Peninsular India and the southern edge of Eurasia (Tibet), along with the related intermediate continental slices, it does not necessarily coincide exactly with the limit between Gondwana and a Tethyan continent.

Reconciling the contradicting geophysical and geological facts constitutes the main scientific challenge in the Himalayas. A renewed effort will be necessary in future geodynamic studies; close cooperation with Chinese geologists in Tibet should be established to unravel the complete history of the Himalayas.

\section{Morphology}

The towering mountains one sees today are the expression of recent morphogenesis. Up to the early Pleistocene, the Himalayas must have been rather deceptive mountains, and early man may have had an easier time when crossing the range. The present erosion is not as yet balanced. Even the total volume of the Siwalik molasse represents only a small part of the visible volume of the present Himalayas, contrasting strongly with, for example, the Alps. Recent terraces and river fans are dominated by poorly sorted boulders. Much of the post Pleistocene detritus is still trapped in large basins and terraces along the northern Himalayas. The largest rivers, such as the Indus, Sutlej, Arun and Tsangpo/ Brahmaputra, originated north of the range within Tibet and have cut the rising Himalayas in spectacular gorges at precisely those areas where we find the highest culminations (Nanga Parbat in the west, Everest/Kangchendzönga in the centre and the Namche Bharwa in the east). Even these mighty rivers were not able to transport much of the Himalayan detritus to the south and into the ocean (in spite of the impression given by the large Indus and Ganges deltas).

One of the largest Pleistocene to Recent basins in the north is the impressive Hundes region in the headwaters of the Sutlej river. Equal in size to Switzerland, and elevated to nearly $5000 \mathrm{~m}$, its gravels are cut by nearly vertical canyons

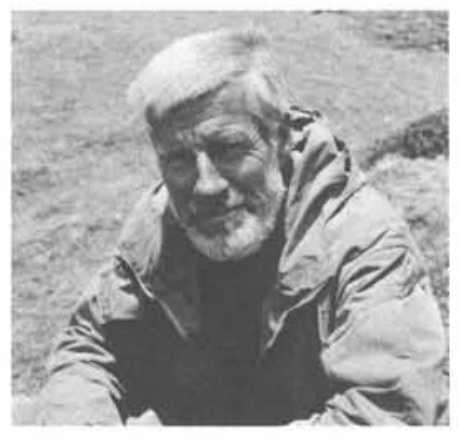

ABOUT THE AUTHOR: Head of the Geological Institute at the Swiss Federal Institute of Technology (ETH) in Zürich from 1958 to 1976, Professor Augusto Gansser spent several years prior to that working as a petroleum geologist, particularly in Colombia and Iran. His life-long interest in Himalayan studies has not waned since his retirement from the ETH. A former chairman of the IUGS Commission on Tectonics, he is currently an active participant in the ICG Working Group 6: "Geodynamics of the Alpine - Himalayan Region, East." up to $1000 \mathrm{~m}$ deep, where the oldest Buddhist relics are found in little known cave monasteries, but where rhinoceros bones indicate also substantial recent uplifts of beds which are still perfectly horizontal. Similar uplifts are recorded in the Karewa lake beds in Kashmir. The above data, combined with the heights of the youngest eroded terraces, suggest 5 $\mathrm{mm}$ per year as the current rate of uplift for the central and northern Himalayas, or five times the rate of uplift for the Alps.

Sites for important monasteries were often selected near large lakes. But most of these lakes have since disappeared. Testimony to their former existence is borne by widespread lake sediments (Fig. 7), deposited when the lakes broke their barriers and descended as catastrophic floods down the valleys. The threat of this happening again is ever present: a few hours of erosion can have a greater effect on the morphology than secular changes. This is an important factor when considering the development of the only really attractive resource potential of the Himalayas - hydroelectric power.

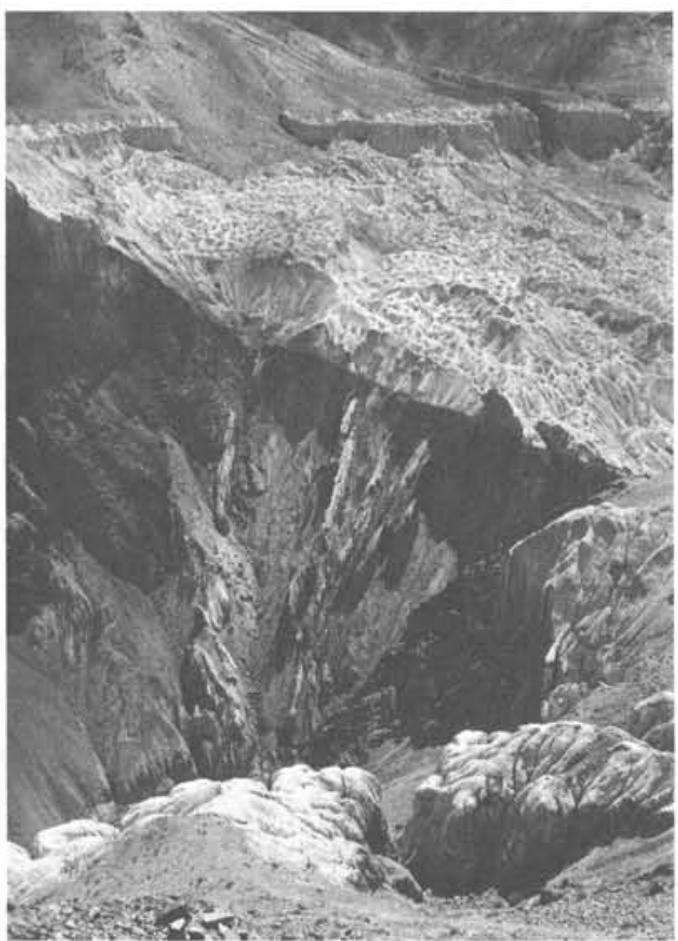

Figure 7. Relics of ancient lake sediments sitting on strongly compressed Triassic flysch in the Suture Zone of Ladakh. This scene is dominated by the famous Lama Yuru monastery founded beside a major lake which has since disappeared.

The peaks, passes and lakes of the northern Himalayas are considered holy in Tibet. Ammonites are particularly revered symbols, and the beautiful Spiti faunas (late Jurassic to earliest Cretaceous) - the saligrams* of the Tibetans - are often left at high passes following a successful crossing. Consequently a geologist unfamiliar with these procedures may be puzzled to find Jurassic ammonites lying on Cambrian shales.

\section{Reference}

Gansser, A., 1964, Geology of the Himalayas: John Wiley \& Sons Ltd., London, 289 p.

* Saligram is the local name for ammonites used as amulets. 